\title{
Orientation effect on thermal and energy performance of vertical
}

\section{greenery systems}

Lan Pan ${ }^{\mathrm{a}, \mathrm{b}}$, Shen Wei ${ }^{\mathrm{c}}$, L.M. Chu ${ }^{\mathrm{b} *}$

a. College of Forestry and Landscape Architecture, South China Agricultural University, Guangzhou, China

b. School of Life Sciences, The Chinese University of Hong Kong, Shatin, NT, Hong Kong SAR, China

c. The Bartlett School of Construction and Project Management, University College London, United Kingdom

${ }^{*}$ Corresponding author. Phone: +852 39436378. Fax: +852 26037732.

Email address: leemanchu@cuhk.edu.hk

\section{Highlights}

- Vertical greenery systems (VGSs) significantly reduced the indoor air temperature of the testing room.

- West-facing VGS showed the highest capacity in wall temperature reduction.

- VGSs reduced the steady-state cooling load of building envelopes by $12 \%$ to $42 \%$.

- VGSs could bring notable passive cooling benefits to both outdoor and indoor environments. 


\begin{abstract}
This study investigated the effects of orientation and weather on the thermal performance of testing rooms with and without vertical greenery systems (VGSs) in humid subtropical Hong Kong. The wall temperatures, ambient air temperatures and indoor air temperatures of both rooms were measured and compared. The effects of mean air temperature, solar radiation, total bright sunshine, relative humidity, mean cloud cover and wind speed on the thermal indicators of VGSs were also explored. Orientation and weather have shown significant effects on the daily maximum temperatures of the walls with and without VGSs. A north-facing VGS showed the highest capacity of reducing ambient temperature $\left(10.1^{\circ} \mathrm{C}\right)$, while the west-facing VGS gave the greatest wall temperature reduction $\left(6.1^{\circ} \mathrm{C}\right)$. The maximum temperature difference between the indoor air temperature of the two testing rooms was $3.6^{\circ} \mathrm{C}$, attributed to the VGS. Solar radiation, total bright sunshine and relative humidity showed significant correlations with the thermal performance of the rooms. Based on simulations, the VGSs could reduce the steady-state cooling load of the building envelopes by $12 \%$ to $42 \%$, depending on their orientations. The highest reduction was found to happen when putting the VGS on the north wall. Overall, the use of VGSs in built environment could bring remarkable passive cooling benefits to both outdoor and indoor environments.
\end{abstract}

Keywords: vertical greenery systems; wall orientation; thermal performance; indoor and outdoor cooling; cooling load.

\title{
1 Introduction
}

With rapid population growth and urbanization, land cover change includes the conversion of vast quantities of natural vegetation to concrete buildings and low-albedo surfaces. This change leads to modification of the thermal conductivity, heat capacity and surface emissivity of the urban environment, which ultimately aggravates the urban heat island (UHI) effect (Landsberg, 1981; Jin and Shepherd, 2005; Getter and Rowe, 2006; Wong et al., 2010; Norton et al., 2015). Owing to global climate change and the more intense UHI effect, heat stress, heat waves and heat spells become more frequent, intense and persistent (Landsberg, 1981). Vertical greenery systems (VGSs) can serve as surrogate green spaces in urban areas dominated by artificial structures and surfaces, 
and as a habitat improvement technique in the built environment, contributing to the enhancement of urban biodiversity and alleviation of the UHI effect (Meier, 1990/91; Alexandri and Jones, 2008; Kontoleon and Eumorfopoulou, 2010; Francis and Lorimer, 2011; Ottelé et al., 2011; Norton et al., 2015; Pan and Chu, 2016; Razzaghmanesh and Razzaghmanesh, 2017).

An appropriate application of vegetation on building envelopes can adequately enhance both building energy performance and occupants' comfort. The placement of VGSs on building walls can help reduce the building's cooling load by decreasing the wall and ambient temperatures (Takakura et al., 2000; Papadakis et al., 2001; Köhler, 2008; Cheng et al., 2010; Perini et al., 2011; Charoenkit and Yiemwattana, 2017), reducing unwanted heat flows from outdoors to indoors (Niu, 2004; Jim and He, 2011), and consequently reducing the need of air conditioning in summer (Kontoleon and Eumorfopoulou, 2010; Wong et al., 2010; Pérez et al., 2011b; Coma et al., 2017; Koc et al., 2017). A considerable amount of solar radiation can be absorbed by the plants for growth and biological functions, including photosynthesis, respiration, transpiration and evaporation from foliage and substrate (Chiang and Tan, 2009; Cheng et al., 2010; Kontoleon and Eumorfopoulou, 2010; Perini et al., 2011; Pérez et al., 2011a; Wood et al., 2014; Hoelscher et al., 2016). The absorption coefficient of a conventional building surface has been estimated to be treble that of a planted wall surface (Kontoleon and Eumorfopoulou, 2010). In addition, the placement of VGSs on building envelopes can also reduce wall temperatures via shading (Bass, 2007; Ip et al., 2007; Lai, 2014; Wong and Baldwin, 2016; He et al., 2017) and provide a certain level of wind barrier effects (Wong et al., 2010; Perini et al., 2011; Pérez et al., 2011b; Wong and Baldwin, 2016).

Due to the great potential of VGSs on temperature reduction and energy savings, there has been a growing body of research on the key parameters affecting the cooling effect of VGSs on buildings. The cooling benefits of VGSs can be influenced by plant characteristics, substrate traits and system design. Plant characteristics of VGSs on building envelopes, such as growth rate, coverage, height and leaf area index, play an important role (Hoyano, 1988; Stec et al., 2004; Wong et al., 2009; Koyama et al., 2013; Wood et al., 2014; Charoenkit and Yiemwattana, 2017). The substrate of a VGS also has an important bearing, and its thickness and the water content define the effectiveness of a plant-covered wall layer by affecting their thermal insulation properties (Cheng et al., 2010; Pérez et al., 2011a). With the rapid development of VGSs in recent years, their cooling effect has been improved in different aspects, such as panel design, material selection and plant choice. An optimization of these aspects can avoid the establishment of heat-sink effects (Pan and Chu, 2016).

Solar heat gain has become the principal cooling load in the dense residential highrise buildings in Hong Kong (Niu, 2004). The azimuth orientation of a VGS on a 
building wall also affects its thermal performance significantly, because it alters the wall temperature and the amount of solar radiation received (Ling et al., 2007; Kontoleon and Eumorfopoulou, 2010; Lai, 2014; Susorova et al., 2014; Jim, 2015). The influence of the orientation of the plant-covered wall section on the thermal behavior of typical buildings has been investigated by Kontoleon and Eumorfopoulou (2010), and the influence of the planted wall has been found to be more notable for east- or west-oriented surfaces (Kontoleon and Eumorfopoulou, 2010; Pérez et al., 2011a; Susorova et al., 2014). Despite these, only few studies have examined the effect of VGS orientation on indoor thermal comfort. In addition, there is a paucity of quantitative study on the effects of weather parameters on the thermal performance of VGSs with respect to orientation. The lack of field thermal performance data in a humid subtropical climate with different orientations creates a knowledge gap that limits the understanding of this significant aspect in vertical greening science.

This study assessed the effects of orientation and weather on the thermal and energy benefits of VGSs. The specific objectives were: 1) to assess the influence of VGSs on the reduction of ambient air temperature, wall temperature and indoor air temperature to identical testing rooms with and without VGSs; 2) to analyze the thermal performance of vertical greening in four orientations on representative summer days; 3 ) to investigate the effects of meteorological parameters on the thermal behavior of vertical greening in four orientations; and 4) to evaluate the cooling potential of VGSs on buildings.

\section{Materials and methods}

\subsection{Study area}

Hong Kong is located on the southern coast of China at N $22^{\circ} 29^{\prime} 46^{\prime \prime}$, E $114^{\circ} 7^{\prime}$ $10^{\prime \prime}$. It has a monsoon-influenced humid subtropical climate, with a wet season from April to September and a dry season from October to March. The cumulative frequency distributions for the air temperature, relative humidity and solar radiation in Hong Kong in 2014 were shown (Figure 1). The annual precipitation is $2300 \mathrm{~mm}$, with an average relative humidity of $78 \%$. The mean temperature from May to October from 1981 to 2010 was higher than $24^{\circ} \mathrm{C}$ (Hong Kong Observatory Monthly Meteorological Normals for Hong Kong [1981-2010], 2015). In the hottest months, i.e. from June to September, the maximum air temperature often exceeds $33^{\circ} \mathrm{C}$. Moreover, because of the global warming phenomenon, the numbers for both hot days (maximum temperature of $33^{\circ} \mathrm{C}$ 
or above) and hot nights (minimum temperature of $28^{\circ} \mathrm{C}$ or above) in Hong Kong have been increased obviously (Hong Kong Observatory, Statistics of Special Weather Events, 2016). According to the local energy use pattern, space-conditioning in buildings accounts for over $21 \%$ of all energy end-uses (Hong Kong Electrical \& Mechanical Services Department (EMSD), 2015). To achieve sustainable development, it is urgent to take actions that can reduce the cooling load of buildings, and VGSs have been considered as a major measure of achieving this goal.

\subsection{Experimental design}

In this study, two testing rooms with identical dimensions $(1.3 \mathrm{~m} \times 1.3 \mathrm{~m} \times 1.0 \mathrm{~m})$ were constructed as mockup on an open ground on the campus of The Chinese University of Hong Kong (Figure 2), one with VGSs and another without. The outside envelope of the mockup consisted of an outer polystyrene board and an inner double gypsum boards, which has an overall thermal transfer value of $13.2 \mathrm{~W} / \mathrm{m}^{2}$, which complies with the requirement of the Code of Practice for Overall Thermal Transfer Value in Buildings 1995 (Hong Kong Buildings Department, 1995) for local energyefficient residential buildings. The U-values for the thermal testing rooms with and without VGS are $0.621 \mathrm{~W} / \mathrm{m}^{2} \mathrm{~K}$ and $0.990 \mathrm{~W} / \mathrm{m}^{2} \mathrm{~K}$ respectively, which were calculated based on the materials of each layer of the external wall and their thermal conductivities. The roof was made of corrugated plastic boards separated by a naturally ventilated air layer to prevent overheating from direct solar radiation. Both mockup rooms were raised $30 \mathrm{~cm}$ from the turf by wooden boards to allow natural ventilation and prevent the vegetation from affecting their temperature.

The VGS panel in each orientation of one mockup room had an area of $1.3 \mathrm{~m}^{2}(1.3$ $\mathrm{m} \times 1.0 \mathrm{~m}$ ); each array had 54 planting pots covering the whole wall area. The pots were planted with Schefflera octophylla, one of the most commonly used plant species for outdoor VGSs in Hong Kong due to its good coverage, foliar density and high temperature tolerance. It is a light-demanding species with a relatively high maximum net photosynthesis rate (Liu et al., 2009). The substrate was a mixture of light growth media, including coco fiber, peat moss, COMPO SANA ${ }^{\circledR}$ Universal Potting Soil, perlite and vermiculite. It has a fibrous texture to facilitate free drainage and aeration, a $\mathrm{pH}$ between 5.6 and 6.3 , and a water holding capacity of $18 \%(\mathrm{v} / \mathrm{v})$. The VGS was watered thoroughly once every day by a battery-controlled irrigation system. The investigation lasted for 12 months from October 2013 to September 2014. 


\subsection{Outdoor and indoor environmental monitoring}

Temperature sensors (DS18B20 1-Wire Digital Thermometer, Dallas Semiconductor, USA) $\left( \pm 0.5^{\circ} \mathrm{C}\right.$ accuracy) were installed in both testing rooms to continuously measure and record temperature data. The temperature measurements included 1) indoor air temperature; 2) wall surface temperature, and 3) air temperature at $40 \mathrm{~cm}$ from the substrate surface, as shown in Figure 2. All sensors were placed 60 $\mathrm{cm}$ above ground level. The substrate moisture content was determined by moisture sensors (ECH2O-EC5 moisture sensors, Decagon Devices, USA) $\left( \pm 0.03 \mathrm{~m}^{3} / \mathrm{m}^{3}\right.$ accuracy). The total solar radiation of the four azimuth orientations was determined by a PYR total solar radiation sensor (pyranometer) (Decagon Devices, USA) $( \pm 5 \%$ accuracy). The sensors were connected to a signal convertor (Ethernet 1-Wire Host Adapters, Embedded Data Systems, USA), and the data were automatically logged by a computer at 30-min intervals. The peak temperature for each day was selected to represent the daily maximum temperature. The temperatures of the four orientations of both testing rooms, i.e. with and without the VGS, were compared under various weather conditions, and the differences in temperature reduction of the four orientations were compared.

Precipitation, relative humidity, solar radiation, air temperature, wind direction and wind speed were recorded by an onsite weather station from October 2013 to September 2014 (1 year). The data were recorded every minute and processed into hourly averages. The cloud cover was obtained from the published meteorological data from the Hong Kong Observatory (Hong Kong Observatory, Daily Extract of Meteorological Observations, 2014).

\subsection{Cooling plant sizing}

To evaluate the cooling effects of VGSs in the four orientations on the optimal sizing of air-conditioning systems which are basic installations in modern buildings in Hong Kong, a cooling plant sizing assessment was carried out in accordance with CIBSE Guide A (CIBSE, 2015). The cooling plant sizing was conducted by means of a steady-state heat balance using Equation (1):

$$
Q_{\text {cool }}=Q_{\text {internal }}+Q_{\text {solar }}+Q_{\text {fabric }}
$$

where $\mathrm{Q}_{\text {cool }}$ is the cooling load of the air-conditioning system in Watts; Qinternal is the internal heat gain from sources such as people and electrical appliances in the building in Watts; $Q_{\text {solar }}$ is the solar energy penetrating through glazing (e.g. windows) in Watts; 
and $Q_{\text {fabric }}$ is the heat passing through all opaque exterior building envelopes, such as external walls and roofs, via heat conduction in Watts.

When comparing buildings with and without vertical greeneries, the major difference regarding heat gains occurs at $\mathrm{Q}_{\text {fabric }}$ as a result of the temperature differences between the indoor and outdoor environments, or more accurately through external walls, as they were covered by the VGS. The other two components, i.e. Qinternal and

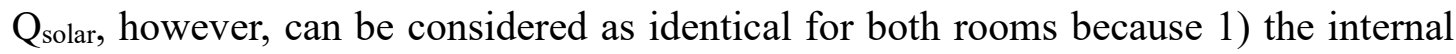
gain occurs indoors, which is independent of the greenery, and 2) plants are generally not placed on the external surface of glazing, so greenery will have little influence on direct solar gains through glazing.

To estimate the cooling impact of VGSs, an example room was proposed. Hong Kong has an average flat size of $38.0 \mathrm{~m}^{2}$, based on an average living space per person of $13.1 \mathrm{~m}^{2}$ and an average household size of 2.9 persons in local public permanent housing, according to the Hong Kong Housing Authority (2016). Therefore, the example room used in this study has a gross floor area of $36 \mathrm{~m}^{2}(6 \mathrm{~m} \times 6 \mathrm{~m})$, with a height of $3 \mathrm{~m}$. It has the same length and width so the difference could be evaluated when putting the VGS on external walls with different orientations. The room has no windows or doors because generally the greenery will not cover them.

Equation (2) was used to calculate the heat transfer through one external wall, in which $U$ is the heat transfer coefficient (in $\mathrm{W} / \mathrm{m}^{2}{ }^{\circ} \mathrm{C}$ ), A is the surface area of each wall (in $\left.\mathrm{m}^{2}\right), \Delta \mathrm{T}$ is the difference between the indoor $\left(\mathrm{T}_{\text {in }}\right)$ and outdoor $\left(\mathrm{T}_{\text {out }}\right)$ temperatures $\left({ }^{\circ} \mathrm{C}\right)$. In this calculation, $\mathrm{T}_{\text {in }}=25^{\circ} \mathrm{C}$, as recommended in CIBSE Guide A (CIBSE, 2015) for summer applications. When there is no vertical greenery, $\mathrm{T}_{\text {out }}$ is taken from the measured values at the onsite weather station from October 2013 to September 2014 (1 year), with a $99 \%$ confidence interval, which means that the temperature is below this level for $99 \%$ of the time. When the vertical greenery was installed, $\mathrm{T}_{\text {out }}$ was taken from the temperature sensor located inside the plant canopy in the VGSs in the four orientations of the testing rooms, with $99 \%$ confidence intervals as well.

$$
Q_{\text {facade }}=U \cdot A \cdot \Delta T=U \cdot A \cdot\left(T_{\text {out }}-T_{\text {in }}\right)
$$

Few assumptions were made in Equation (2) for the prediction. The value of $U$ for the external wall was taken as $0.35 \mathrm{~W} / \mathrm{m}^{2 \circ} \mathrm{C}$, as suggested by the UK regulations Part L1A (HM Government, 2010). When comparing the cooling impact of VGSs in the four orientations, the temperature data from the weather station were taken for conditions without VGSs, while the mean temperatures taken inside the plant canopy at the four orientations were used for conditions with VGSs. In addition, the heat gain for each orientation was calculated and compared to determine the best orientation for VGSs 
regarding thermal performance.

\section{Results and discussion}

\subsection{Diurnal temperature of a typical summer day}

\subsubsection{Wall surface temperature}

On sunny summer days, the wall with a VGS demonstrated drastic suppression of the surface temperature and fluctuation amplitude compared with the bare wall, mainly due to the thermal effect of the VGS (Figure 3). A comparison between the temperature dynamics of walls with and without VGSs in the four orientations is presented in Table 1.

The biggest temperature difference between the bare and planted walls was $6.4^{\circ} \mathrm{C}$, occurred at $1530 \mathrm{~h}$ in the wall facing west (Table 1) because the greatest solar radiation of the day in summer came from the west at $1530 \mathrm{~h}$ (Figure 4). The temperature reduction became largest around noon time when it was hottest outside, maximizing the benefits of VGSs. In terms of mean wall temperature reduction during the entire day, the VGS on the wall facing west appeared to have the best cooling efficiency in the daytime, reaching a maximum temperature reduction $>2.4^{\circ} \mathrm{C}$. The orientation of VGSs in building envelopes significantly affects the temperature reduction and thermal performance. Alexandri and Jones (2008) suggested that the daily average temperature decrease inside the urban canyon in Athens was $3.0^{\circ} \mathrm{C}$ for east and west, and $2.2^{\circ} \mathrm{C}$ for north and south, respectively, which may attribute to the more solar irradiation received in the east and west orientated VGSs. In addition, for Hong Kong, a city in a lowlatitude region in the northern hemisphere, a north-facing wall receives the highest solar radiations in the morning and afternoon in July.

\subsubsection{Ambient temperature}

The east-facing VGS showed the greatest capacity for ambient temperature reduction. The biggest difference between the ambient temperatures of both testing rooms was $8.4^{\circ} \mathrm{C}$, occurred at $0730 \mathrm{~h}$ in the wall facing east, followed by the northfacing wall (Figure 5 and Table 2). The evapotranspiration of VGSs can bring prominent ambient temperature reduction, which indicates that their installation has a promising effect on alleviating building canyon heat and the UHI effect (Alexandri and Jones, 2008). 


\subsubsection{Indoor air temperature}

The indoor air of the planted testing room experienced a narrow temperature range, which was between $27.9^{\circ} \mathrm{C}$ and $34.6^{\circ} \mathrm{C}$. The bare testing room, however, had a wider and hotter temperature range, which was between $28.0^{\circ} \mathrm{C}$ and $38.2^{\circ} \mathrm{C}$, as shown in Figure 6. The indoor air temperature of the planted testing room was always lower than that of the bare testing room, throughout the 24 hours, with a maximum temperature reduction of $3.6^{\circ} \mathrm{C}$ at $1700 \mathrm{~h}$. A temperature difference bigger than $3^{\circ} \mathrm{C}$ lasted for over five hours between 1230 and 1800 .

The use of VGSs on the testing room showed a significant cooling effect which was higher during daytime than nighttime (Chen et al., 2013; Charoenkit and Yiemwattana, 2017). The cooler indoor air that was attributed to the VGS could contribute to energy savings from air conditioning in summer. The maximum temperature difference between the indoor air temperature with and without the VGS was $3.6^{\circ} \mathrm{C}$ (Figure 6). A study of VGSs on an experimental building in Hong Kong showed that the indoor temperature of the flat with a south-west facing VGS was about $1^{\circ} \mathrm{C}$ lower than that of the flat without VGSs on a typical summer sunny day (Pan and Chu, 2016). The testing room in this study was covered by VGSs in all four orientations, bringing a larger temperature reduction.

VGSs serve as a heat sink for solar energy absorbed during the day mainly because of the thermal capacity of the substrate moisture, which is released gradually at night to retain a higher nocturnal temperature. Although the VGS could be an occasional heat sink, the latent heat used in evapotranspiration reduced the amount of long-wave radiation released into the environment (Wong et al., 2010), which confirmed that VGSs have the potential to alleviate the UHI effect through evapotranspiration during summer at both building and city scales.

\subsection{Weather effect on daily maximum temperature in July}

\subsubsection{Wall surface temperature}

The daily maximum temperatures of the bare walls in all four orientations were consistently higher than those of the planted walls (Figure 7 and Table 3). The daily maximum temperatures of the bare walls were higher, exceeding $35^{\circ} \mathrm{C}$ on 23 of the 33 days $(69.7 \%)$ for the west-facing wall, but only $13-14$ of the 33 days for the other orientations. In contrast, the daily maximum temperatures of the planted walls facing 
north, east and south were never higher than $35^{\circ} \mathrm{C}$. The VGSs on the west-facing wall had the best thermal performance regarding the daily maximum temperature for both bare and planted walls. The maximum reduction in the daily maximum temperature by VGSs was highest in the westerly walls, ranging from $0.9^{\circ} \mathrm{C}$ (18 July) to $6.1^{\circ} \mathrm{C}(15$ July). This variation indicated substantial diurnal variations in the VGSs thermal performance.

The daily maximum temperature of the planted walls in all four orientations showed similar patterns, with no great temperature difference between them (Figure 7). The drastic reduction in the daily maximum temperature is attributed to passive shading and insulation in tandem with active evapotranspiration (Jim and Peng, 2012). Jim and He (2011) found that the maximum exterior wall surface temperature was reduced by $10^{\circ} \mathrm{C}$. In this study, the westerly VGS reduced the daily maximum wall temperature by $6.1{ }^{\circ} \mathrm{C}$ on a typical sunny day (15 July; Table 3$)$. The different VGS designs, wall materials used, and interior space dimensions in the experiment could have accounted for this finding. The capacity of the VGSs to limit fluctuations in the wall temperature is advantageous for prolonging the lifespan of buildings (Wong et al., 2010).

\subsubsection{Ambient temperature}

The mean daily maximum ambient temperatures of the planted walls facing south $\left(37.0^{\circ} \mathrm{C}\right)$ and west $\left(37.3^{\circ} \mathrm{C}\right)$ were higher than those facing east $\left(31.9^{\circ} \mathrm{C}\right)$ and north $\left(31.4^{\circ} \mathrm{C}\right.$ ) (Figure 8 and Table 4$)$. The westerly bare and planted walls exceeded $40^{\circ} \mathrm{C}$ for the longest time (17 and 2 days, respectively). The maximum ambient temperature differences for the southerly and westerly walls were $3.2^{\circ} \mathrm{C}(14 \mathrm{July})$ and $4.9^{\circ} \mathrm{C}(26$ July), respectively, and those for the northerly and easterly walls were $10.1^{\circ} \mathrm{C}(29 \mathrm{July})$ and $8.9^{\circ} \mathrm{C}$ (21 July).

The planted walls showed variations in the reduction of daily maximum temperature of ambient air by orientations (Figure 8). The greater fluctuation of the ambient temperature than the wall temperature can be accounted for by the discrepancy between the temperature trends of the surface and ambient air of the planted wall. In addition, the small size of the testing rooms increased heat conductance, so similar patterns were obtained for the daily maximum temperature of the walls in the four orientations.

The daily maximum ambient air temperature between the bare and planted walls facing north and east were $10.1^{\circ} \mathrm{C}$ (29 July) and $8.9^{\circ} \mathrm{C}$ (21 July), respectively. Wong et al. (2010) found that the air temperature reduction of the best VGS among the eight at $30 \mathrm{~cm}$ away from the wall was $1.7^{\circ} \mathrm{C}$. The pronounced thermal performance of VGSs in this study could be attributed to the interactions between canopy characteristics and 
microclimatic parameters such as wind velocity. The differences in soil moisture and plant stomatal responses (data not shown) in four orientations probably account for the difference between the daily maximum ambient temperature reductions in four orientations in Figure 8. The high direct solar radiation and outdoor air temperature in the west and south orientations caused greater water loss in the soil and less evaporation from the soil in VGSs in the west and south, also depressed foliar evapotranspiration due to the stomatal closure on plants in VGSs facing west and south.

\subsubsection{Indoor air temperature}

For indoor air, the mean daily maximum temperature of the bare wall $\left(34.7^{\circ} \mathrm{C}\right)$ was higher than that of the planted wall $\left(32.8^{\circ} \mathrm{C}\right)$ by $1.9^{\circ} \mathrm{C}$ (Figure 9$)$. The difference in the daily maximum temperatures between the bare and planted testing rooms ranged from $0.6^{\circ} \mathrm{C}$ (13 August) to $3.6^{\circ} \mathrm{C}$ (15 July). The daily maximum temperatures of the bare testing room were higher, with 15 of the 33 days $(55.6 \%)$ exceeding $35^{\circ} \mathrm{C}$, whereas the temperature exceeded $35^{\circ} \mathrm{C}$ in the planted testing room in 2 days.

The maximum temperature reduction of interior space in another similar study in a subtropical monsoon climate was $1.1^{\circ} \mathrm{C}$ (Chen et al., 2013). The difference in the daily maximum temperature between the planted and bare testing rooms was $3.6^{\circ} \mathrm{C}(15$ July; Figure 9). The mean reduction in the daily maximum temperature between the rooms from 14 July to 15 August 2014 was $1.9^{\circ} \mathrm{C}$ (Figure 9). The VGSs in all four orientations in this study displayed a more pronounced cooling effect on the interior space.

It has been generally found that temperature reduction by VGSs is more profound in warmer than cooler weather (Riley, 2017). With the warming trend in the global air temperature and the UHI effect, the number of hot days (maximum temperature of $33^{\circ} \mathrm{C}$ or above) and hot nights (minimum temperature of $28^{\circ} \mathrm{C}$ or above) have apparently risen in Hong Kong (Hong Kong Observatory, Statistics of Special Weather Events, 2016). Therefore, the cooling effects of VGSs on the daily maximum temperatures of the building envelope are beneficial to this phenomenon.

\subsubsection{Maximum temperature reduction in four orientations}

The VGSs in the four orientations resulted in remarkable variations in the daily maximum temperatures between the bare and planted testing rooms under different weather conditions. The VGS on the west-facing wall showed the greatest vegetation cooling and a significantly higher daily maximum wall temperature reduction on sunny days $\left(4.7^{\circ} \mathrm{C}\right.$; Figure 10$)$. The planted north-facing wall had the highest temperature 
reduction ability in daily maximum ambient air temperature on sunny days $\left(8.0^{\circ} \mathrm{C}\right)$, followed by the east-facing wall $\left(6.1^{\circ} \mathrm{C}\right) . S$. octophylla in the VGSs in the four orientations on the planted testing room had the greatest ability to reduce the indoor air temperature on sunny days $\left(2.6^{\circ} \mathrm{C}\right.$; Figure 10$)$. The difference in the daily maximum indoor air temperature appeared more significant on hot days, comparing to relatively cool days (Figures 9 and 10).

The two-way ANOVA has showed significant effects of both orientation and weather on the daily maximum wall temperatures, the daily maximum ambient air temperatures and the daily maximum indoor air temperatures of the bare and the planted walls from 14 July to 15 August 2014 (Table 5). However, there were no significant interactions between these two factors and the daily maximum temperatures.

3.2.5 Correlations between weather parameters and thermal-effects indicators of VGSs

Correlations between the key meteorological variables and thermal indicators of VGSs from 14 July to 15 August 2014 were identified using Pearson's correlation coefficient (Table 6). For the north- and east-facing walls, the mean air temperature, the solar radiation, and the total bright sunshine showed significant and positive correlations $(\mathrm{p}<0.05$ or $\mathrm{p}<0.01)$ with all six thermal indicators, and relative humidity and mean cloud cover showed significant but negative correlations $(\mathrm{p}<0.05$ or $\mathrm{p}<0.01)$. For the west-facing wall, the mean air temperature, solar radiation, and the total bright sunshine showed significant and positive correlations $(\mathrm{p}<0.01)$ with all six thermal indicators, and relative humidity showed significant but negative correlations $(p<0.01)$ with all six thermal indicators.

The mean air temperature, the solar radiation, and the total bright sunshine showed significant and positive correlations $(\mathrm{p}<0.01)$ with the daily maximum indoor temperatures of the bare and the planted testing rooms and a reduction in the indoor temperature, and the relative humidity and the mean cloud cover showed significant but negative correlations $(\mathrm{p}<0.01$; Table 7$)$.

The solar radiation, the total bright sunshine and the relative humidity showed the strongest correlations with the thermal indicators. The mean air temperature, the solar radiation and the total bright sunshine showed positive correlations with temperatures, and the relative humidity, the mean cloud cover and the wind speed showed negative correlations with temperatures (Tables 6 and 7). Hot sunny days had lower relative humidity levels than cloudy and rainy days in summer. Less cloud cover leads to more solar radiation and total bright sunshine, which result in a higher mean air temperature. A low relative humidity level, high mean air temperature and solar radiation induced high ambient air temperatures around the bare and planted testing rooms, high 
temperatures of the bare and planted walls, and high indoor air temperatures in the bare and planted testing rooms. Evapotranspiration of vertical greenery leads to cooling by releasing latent heat from the VGSs. The cooling effect is stronger on hot sunny days with higher mean air temperatures and solar radiation than on cloudy and rainy days.

Wind can enhance cooling of VGSs by evapotranspiration and blow away heat from the surface. The wind speed exerted a greater influence on the temperatures of both bare and planted walls than the other weather parameters, but less influence on the ambient air temperatures and indoor air temperatures of the walls (Tables 6 and 7). These findings indicate that the influence of wind via evapotranspiration of VGSs resulted mainly from the intermediary effect of evapotranspiration.

\subsection{Cooling plant sizing}

Based on the mean monthly ambient air temperature of the testing rooms for over 1 year, the suggested indoor temperature $\left(25^{\circ} \mathrm{C}\right)$ and the days of the month, the required cooling plant size for the example room was calculated for conditions with and without VGSs, and the results are shown in Table 8. The area of the walls of the example rooms for the analysis of cooling plant size through a steady-state heat balance equation was $18 \mathrm{~m}^{2}$. The heat conduction reduction of four orientations ranged from $12.4 \%$ to $41.6 \%$ (Table 8).

Of the temperatures in different orientations, the north- and east-facing walls with VGSs had greater reductions in cooling load than the other walls. The solar reception of VGSs in four orientations significantly varied in terms of intensity, peak level, duration and timing (Figure 4). The high solar radiation and long duration of bright sunlight in the west in Hong Kong cause the depletion of stored substrate moisture and reserved water in the planter boxes of the VGSs in the west-facing walls, and decreased transpiration. The low substrate moisture (data not shown), and perhaps the low humidity of the VGSs in the west in tandem with depressed evapotranspiration also accounted for the difference in the thermal performance of VGSs in four orientations. Furthermore, the low substrate moisture, strong solar radiation and heat west-facing walls create an exposed and harsh environment for the vegetation, which is likely to cause burns on the leaves and restrict canopy coverage, and lead to a decline in canopy evaporation and the cooling effect. In addition, midday depression of the net photosynthetic rate and stomatal conductance (Tenhunen et al., 1981 and 1984; Roessler et al., 1985; Collatz et al., 1991) lead to low relative humidity in the ambient environment, which also affects the thermal performance of the VGSs in four orientations. 
The pronounced thermal performance of the VGSs in our study could be attributed to the interactions between the characteristics of the canopy and other microclimatic parameters such as the moisture in the soil and air and the wind velocity, so the steadystate heat transfers of the VGSs in different orientations varied significantly. The application of VGSs in four orientations of the building envelopes could reduce steadystate heat conduction by $12 \%$ to $42 \%$. Alexandri and Jones (2008) suggested that the energy savings in Hong Kong could reach up to $66 \%$ based on a micro-scale model. The empirical data from the buildings in this study deviated from the estimated data based on modeling due to the different research methods used, and the various factors affecting heat conduction. Nevertheless, this agrees with the results of another empirical study in Hong Kong with 16\% of the energy saving for cooling by the VGSs on the south-west facing wall in August and September (Pan and Chu, 2016). This study demonstrates the significant potential of the application of VGSs to high-rise buildings for energy savings, although the actual amount saved would be affected by climate, system design, and the energy used for air conditioning. In addition, the cost of energy consumption through the cooling effect of VGSs on the building envelopes could be reduced, and the initial investment on VGSs could be paid back in roughly 40 years (Pan and Chu, 2016). Solar heat gain has become the dominant air-conditioning load in the dense residential high-rise buildings in Hong Kong (Niu, 2004). Thus, the orientation of vertical greeneries plays a significant role in the notable passive cooling benefits to both outdoor and indoor environments. Green building approaches can contribute to energy saving in conventional high-rises in dense built environments and urban heat mitigation.

\section{Conclusions}

Orientation and weather have shown significant but independent contributions to the reduction of temperature by VGSs. The experimental approach furnished useful data to assess temperature regimes under different orientations. Four orientations have diverse reception of solar energy incident with notable bearing on temperature regimes of the thermal testing rooms. In terms of the daily maximum wall temperatures, the VGS in the west-facing facade showed the best thermal performance. The major effect of orientations on temperature reduction was the pattern of solar radiation under diurnal alteration. In addition, solar radiation, total bright sunshine and relative humidity have the strongest correlations with thermal indicators; they were the most critical meteorological parameters for the thermal performance of VGSs. Wind could further reduce temperatures by enhancing evapotranspiration cooling of VGSs and by blowing 
away heat from the wall surfaces. In addition, VGSs could decrease the cooling load and enhance the indoor thermal environment. VGSs could reduce the optimal cooling plant size of the building envelopes in four orientations by $12-42 \%$; the steady-state cooling load when putting VGS on the north was the lowest. Overall, VGSs installed on building walls not only play a significant role in alleviating the problems of global warming and climate change by energy saving, but also contributed to mitigating the UHI effect and improving the urban microclimate due to their hygrothermal performance. This performance is determined by a combination of factors, including the substrate moisture content as well as the shading and insulating effects of greenery.

This experiment on VGSs adopted a mockup room of reduced scale to verify the hygrothermal impact of VGSs on both building and the built environment. The effects of construction material, building type and urban morphology could be further studied to determine their influences on building's thermal performance. The materials of the testing rooms used in this study have typical insulating effect and are within the required range of overall thermal transfer properties. The results could be applied to other premises that conform to the technical standards in Hong Kong and other subtropical cities.

The cooling benefit was attenuated by the synergistic development of the building heat-sink effect. This study investigated only the feasibility of installing VGSs in four orientations of the testing room to reduce the cooling load of air conditioning. More empirical studies of a wider variety of VGSs can advance the understanding of thermal performance of VGSs in subtropical areas. Experiments with larger VGSs on genuine building envelopes need to be carried out to validate the data used in this study, regarding to the energy savings associated with VGSs.

\section{Acknowledgements}

We thank Mr Ben Yeung and Ms PY Lai for their technical assistance, Everplant Technology Limited for the construction of the VGSs on the testing room, and the Department of Geography and Resource Management (CUHK) for their provision of venue for the experimental setup. The study was supported by a research grant (ECF Project 24/2010) from the Environment and Conservation Fund of the Government of the Hong Kong Special Administrative Region. 


\section{References}

Alexandri E, Jones P. 2008. Temperature decrease in an urban canyon due to green walls and green roofs in diverse climates. Building and Environment, 43: 480-493.

Bass B. 2007. Green roofs and green walls: potential energy savings in the winter. Adaptation and Impacts Research Division, Environment Canada at the University of Toronto Centre for Environment.

Charoenkit S, Yiemwattana S. 2017. Role of specific plant characteristics on thermal and carbon sequestration properties of living walls in tropical climate. Building and Environment, 115: 67-79.

Chen Q, Li B, Liu X. 2013. An experimental evaluation of the living wall system in hot humid climate. Energy and Building, 61: 298-307.

Cheng CY, Cheung KKS, Chu LM. 2010. Thermal performance of a vegetated cladding system on facade walls. Building and Environment, 45: 1779-1787.

Chiang K, Tan A. 2009. Vertical Greenery for the Tropics. Singapore: National Parks Board, National University of Singapore, and Building and Construction Authority CIBSE. 2015. Environmental Design-CIBSE Guide A. Norwich: Chartered Institution of Building Services Engineers.

Collatz GJ, Ball JT, Grivet C, Berry JA. 1991. Physiological and environmental regulation of stomatal conductance, photosynthesis and transpiration: a model that includes a laminar boundary layer. Agricultural and Forest Meteorology, 54: 107-136. Coma J, Pérez G, Gracia A, Burés S, Urrestarazu M, Cabeza LF. 2017. Vertical greenery systems for energy savings in buildings: A comparative study between green walls and green facades. Building and Environment, 111: 228-237

Francis RA, Lorimer J. 2011. Urban reconciliation ecology: The potential of living roofs and walls. Journal of Environmental Management, 92: 1429-1437.

Getter KL, Rowe DB. 2006. The role of extensive green roofs in sustainable development. HortScience, 41: 1276-1285.

He Y, Yu H, Ozaki A, Dong N, Zheng S. 2017. An investigation on the thermal and energy performance of living wall system in Shanghai area. Energy and Buildings, 140: 324-335.

HM Government. 2010. The Building Regulations 2010: Conservation of fuel and power in new dwelling. Approved Document L1A, London: NBS, part of RIBA Enterprise Ltd. 
Hoelscher MT, Nehls T, Jänicke B, Jänicke B, Wessolek G. 2016. Quantifying cooling effects of facade greening: shading, transpiration and insulation. Energy and Buildings, 114: 283-290.

Hong Kong Buildings Department. 1995. Code of Practice for Overall Thermal Transfer Value in Buildings 1995. Available at: http://www.bd.gov.hk/english/documents/code/e_ottv.htm [accessed 2.02.18] Hong Kong Electrical \& Mechanical Services Department (EMSD), Hong Kong Energy End Use Data 2015, 2015. Available at: http://www.emsd.gov.hk/filemanager/en/content_762/HKEEUD2015.pdf (accessed 2.02.18).

Hong Kong Housing Authority. 2016. Housing in Figures 2016. Available at: http://www.housingauthority.gov.hk/en/common/pdf/about-us/publications-andstatistics/HIF.pdf (accessed 2.02.18).

Hong Kong Observatory Daily Extract of Meteorological Observations. Available at: http://www.hko.gov.hk/cis/climat_c.htm (accessed 2.02.18).

Hong Kong Observatory Monthly Meteorological Normals for Hong Kong (19812010). Available at: http://www.weather.gov.hk/cis/normal/1981_2010/normals_e.htm (accessed 2.02.18).

Hong Kong Observatory, Statistics of Special Weather Events, 2016. Available at: http://www.hko.gov.hk/cis/statistic/vhotday_statistic_e.htm (accessed 2.02.18).

Hoyano A. 1988. Climatological uses of plants for solar control and the effects on the thermal environment of a building. Energy and Buildings, 11: 181-199.

Ip K, Lam MHY, Miller A. 2007. Assessing the shading performance of climbing plant canopies. In: Wittkopf SK, TB Kiang (Eds.). 24th International Conference on Passive and Low Energy Architecture PLEA2007, National University of Singapore, Singapore, pp. 437-443.

Jim CY, He H. 2011. Estimating heat flux transmission of vertical greenery ecosystem. Ecological Engineering, 37: 1112-1122.

Jim CY, Peng LLH. 2012. Weather effect on thermal and energy performance of an extensive tropical green roof. Urban Forestry \& Urban Greening, 11: 73-85.

Jim CY. 2015. Thermal performance of climber green walls: Effects of solar irradiance and orientation. Applied Energy, 154: 631-643.

Jin M, Shepherd M. 2005. Inclusion of urban landscape in a climate model: how can satellite data help? Bulletin of the American Meteorological Society, 86: 681-689. 
Koc CB, Osmond P, Peters A. 2017. Towards a comprehensive green infrastructure typology: a systematic review of approaches, methods and typologies. Urban Ecosystems, 20: 15-35.

Köhler M. Green facades - a view back and some visions. Urban Ecosystems, 2008, 11: 423-436

Kontoleon KJ, Eumorfopoulou EA. 2010. The effect of the orientation and proportion of a plant-covered wall layer on the thermal performance of a building zone. Building and Environment, 45: 1287-1303.

Koyama T, Yoshinaga M, Hayashi H, Maeda KI, Yamauchi A. 2013. Identification of key traits contributing to the cooling effects of green façades using free standing walls. Building and Environment, 66: 96-103.

Lai PY. 2014. Species Selection for Temperature Reduction and Water Conservation in Vertical Greening. MPhil Thesis, The Chinese University of Hong Kong, Hong Kong. Landsberg HE. 1981. The Urban Climate. New York: Academic Press.

Ling CS, Ahmad MH, Ossen DR. 2007. The effect of geometric shape and building orientation on minimising solar insolation on high-rise buildings in hot humid climate. Journal of Construction in Developing Countries, 12: 27-38.

Liu Z, Shen W, Wen D. 2009. Growth and photosynthetic characteristics of six native tree species seedlings grown on bare land and beneath secondary forest in Nan'ao Island. Ecology and Environmental Sciences, 18: 621-628.

Meier AK. 1990/91. Strategic landscaping and air-conditioning savings: A literature review. Energy and Buildings, 15-16: 479-486.

Niu JL. 2004. Some significant environmental issues in high-rise residential building design in urban areas. Energy and Building, 36: 1259-1263.

Norton BA, Coutts AM, Livesley SJ, Harris RJ, Hunter AM, Williams NS. 2015. Planning for cooler cities: a framework to prioritise green infrastructure to mitigate high temperatures in urban landscapes. Landscape and Urban Planning, 134: 127-138.

Ottelé M, Perini K, Fraaij ALA, Haas EM, Raiteri R. 2011. Comparative life cycle analysis for green facades and living wall systems. Energy and Buildings, 43: 34193429.

Pan L, Chu LM. 2016. Energy saving potential and life cycle environmental impacts of a vertical greenery system in Hong Kong: A case study. Building and Environment, 96: 293-300.

Papadakis G, Tsamis P, Kyritsis S. 2001. An experimental investigation of the effect of shading with plants for solar control of buildings. Energy and Buildings, 33: 831-836. 
Pérez G, Rincón L, Vila A, González JM, Cabeza LF. 2011a. Green vertical systems for buildings as passive systems for energy savings. Applied Energy, 88: 4854-4859.

Pérez G, Rincón L, Vila A, González JM, Cabeza LF. 2011b. Behaviour of green facades in Mediterranean Continental climate. Energy Conversion and Management, 52: 1861-1867.

Perini K, Ottelé M, Fraaij ALA, Haas EM, Raiteri R. 2011. Vertical greenery systems and the effect on air flow and temperature on the building envelope. Building and Environment, 46: 2287-2294.

Razzaghmanesh M, Razzaghmanesh M. 2017. Thermal performance investigation of a living wall in a dry climate of Australia. Building and Environment, 112: 45-62

Riley B. 2017. The state of the art of living walls: Lessons learned. Building and Environment, 114: 219-232.

Roessler PG, Monson RK. 1985. Midday depression in net photosynthesis and stomatal conductance in Yucca glauca. Oecologia, 67: 380-387.

Stec WJ, Van Paassen AHC, Maziarz A. 2004. Modelling the double skin facade with plants. Energy and Buildings, 37: 419-427.

Susorova I, Azimi P, Stephens B. 2014. The effects of climbing vegetation on the local microclimate, thermal performance, and air infiltration of four building façade orientations. Building and Environment, 76: 113-124.

Takakura T, Kitade S, Goto E. 2000. Cooling effect of greenery cover over a building. Energy and Buildings, 31: 1-6.

Tenhunen JD, Lange O L, Braun M. 1981. Midday stomatal closure in Mediterranean type sclerophylls under simulated habitat conditions in an environmental chamber. Oecologia, 50: 5-11.

Tenhunen JD, Lange OL, Gebel J, Beyschlag W, Weber JA. 1984. Changes in photosynthetic capacity, carboxylation efficiency, and $\mathrm{CO}_{2}$ compensation point associated with midday stomatal closure and midday depression of net $\mathrm{CO}_{2}$ exchange of leaves of Quercus suber. Planta, 162: 193-203.

Wong I, Baldwin AN. 2016. Investigating the potential of applying vertical green walls to high-rise residential buildings for energy-saving in sub-tropical region. Building and Environment, 97: 34-39.

Wong NH, Tan AYK, Chen Y, Sekar K, Tan PY, Chan D, Chiang K, Wong NC. 2010. Thermal evaluation of vertical greenery systems for building walls. Building and Environment, 45: 663-672.

Wong NH, Tan AYK, Tan PY, Wong NC. 2009. Energy simulation of vertical greenery systems. Energy and Buildings, 41: 1401-1408. 
Wood A, Bahrami P, Safarik D. 2014. Green Walls in High-rise Buildings. Council on Tall Buildings and Urban Habitats, The Image Publishing Group Pty Ltd. 


\section{Figures}
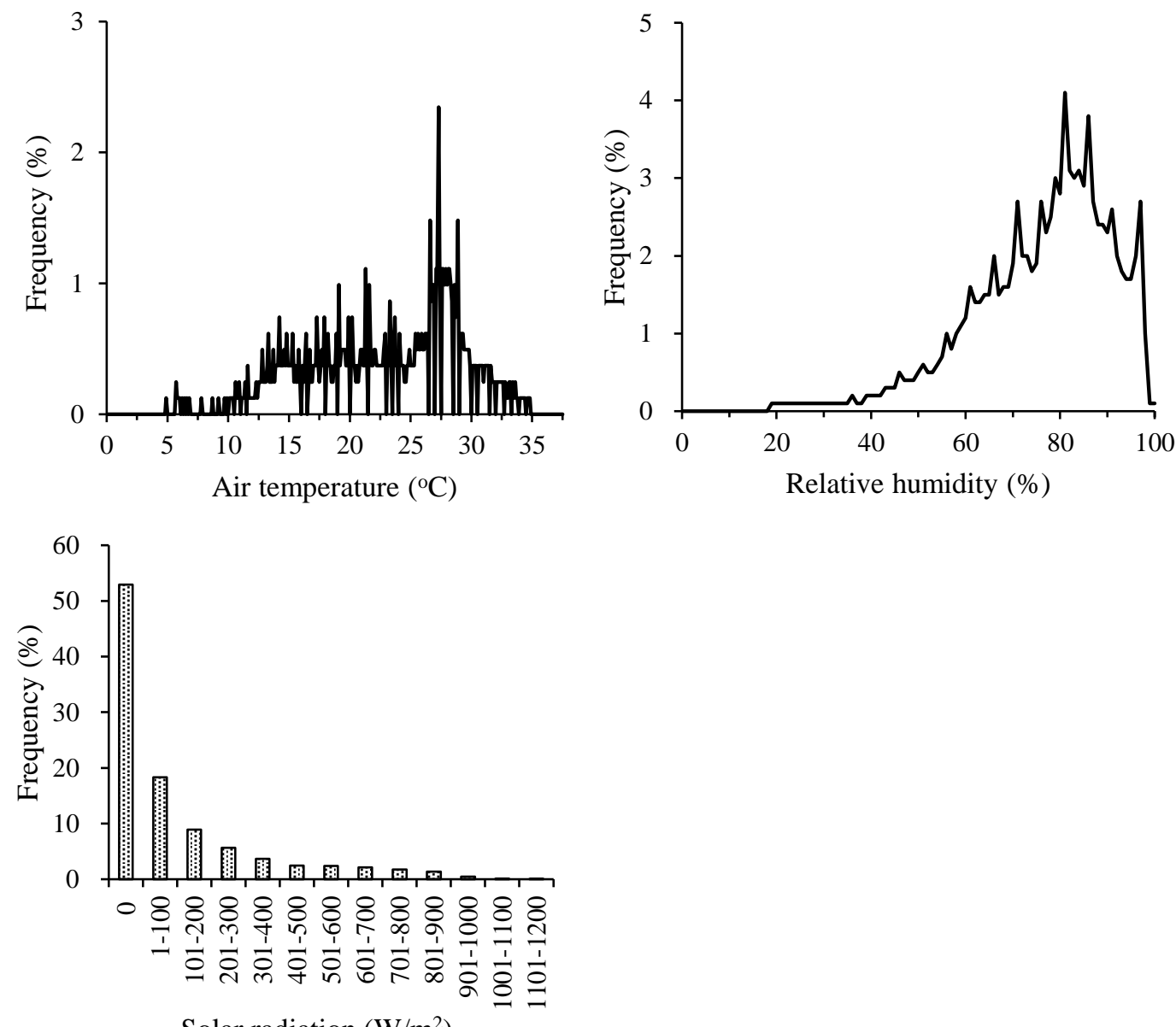

Figure 1. Frequency of occurrence for air temperature, relative humidity and solar radiation in Hong Kong in 2014. 

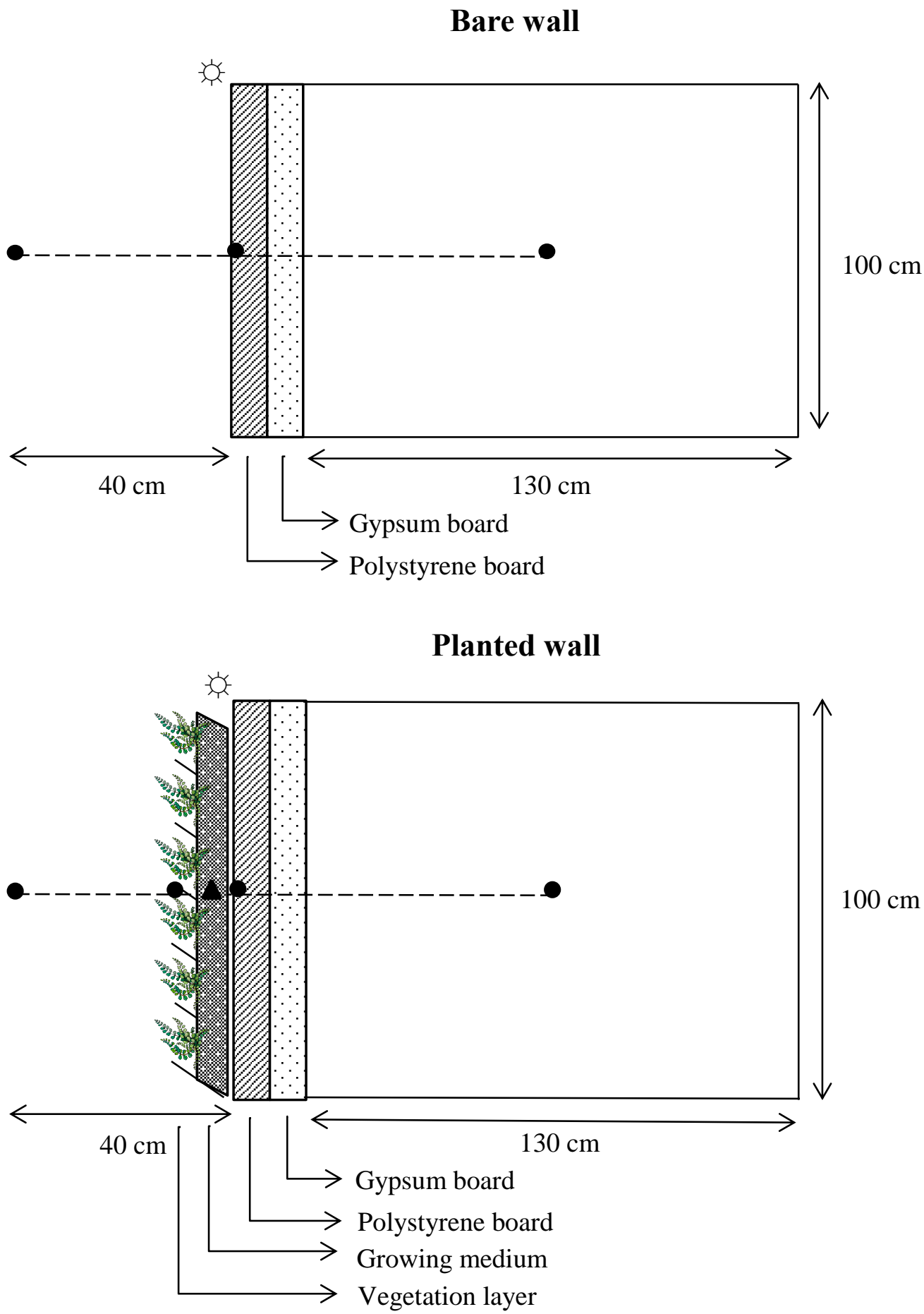

- Air or material temperature sensor

Solar radiation sensor

A Substrate moisture sensor

Figure 2. Testing rooms without and with VGSs in four orientations. 

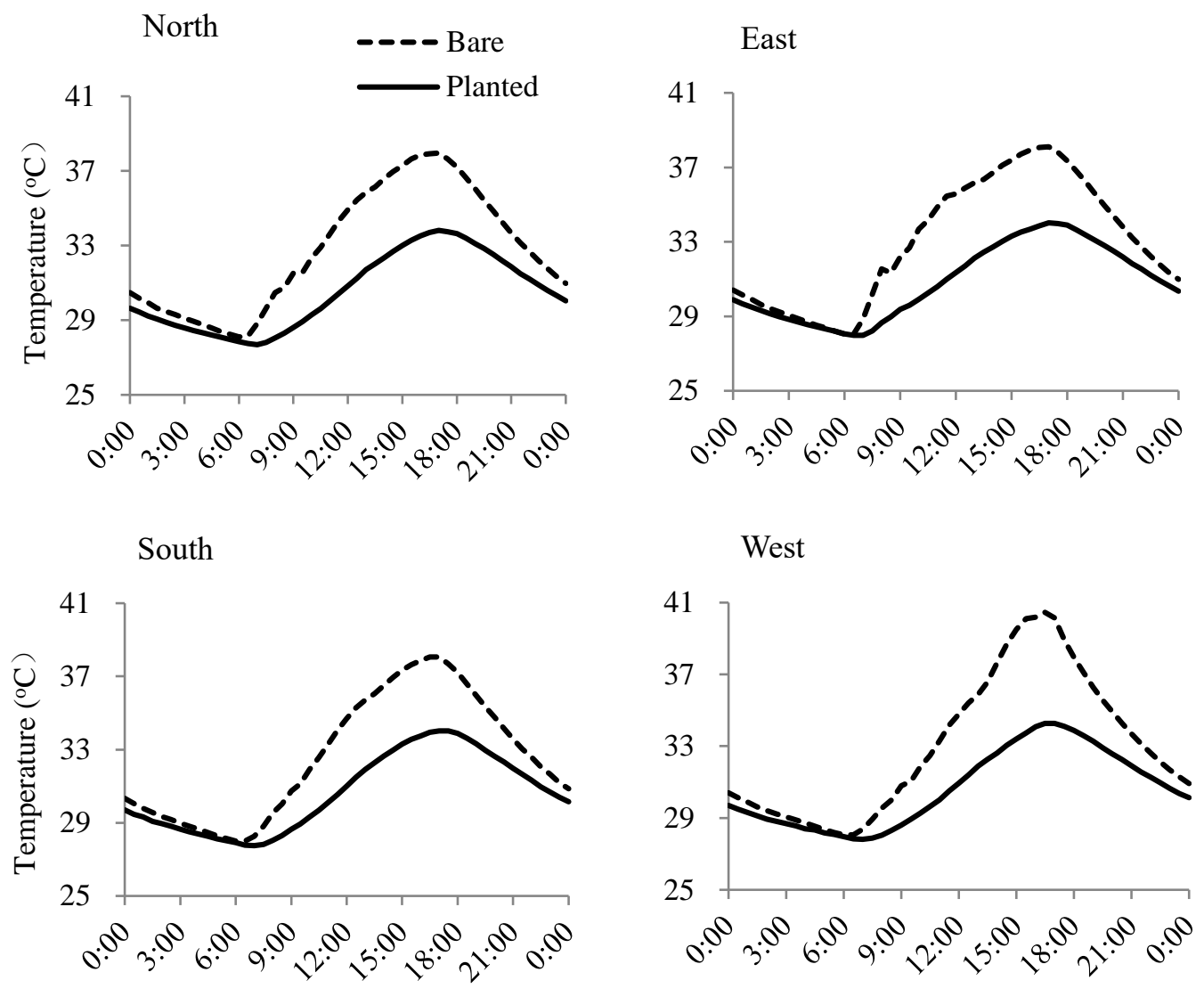

Time

Time

Figure 3. Temperature fluctuations of the bare and planted walls facing north, east, south, and west on 15 July 2014. Values are the mean of three replicates. 


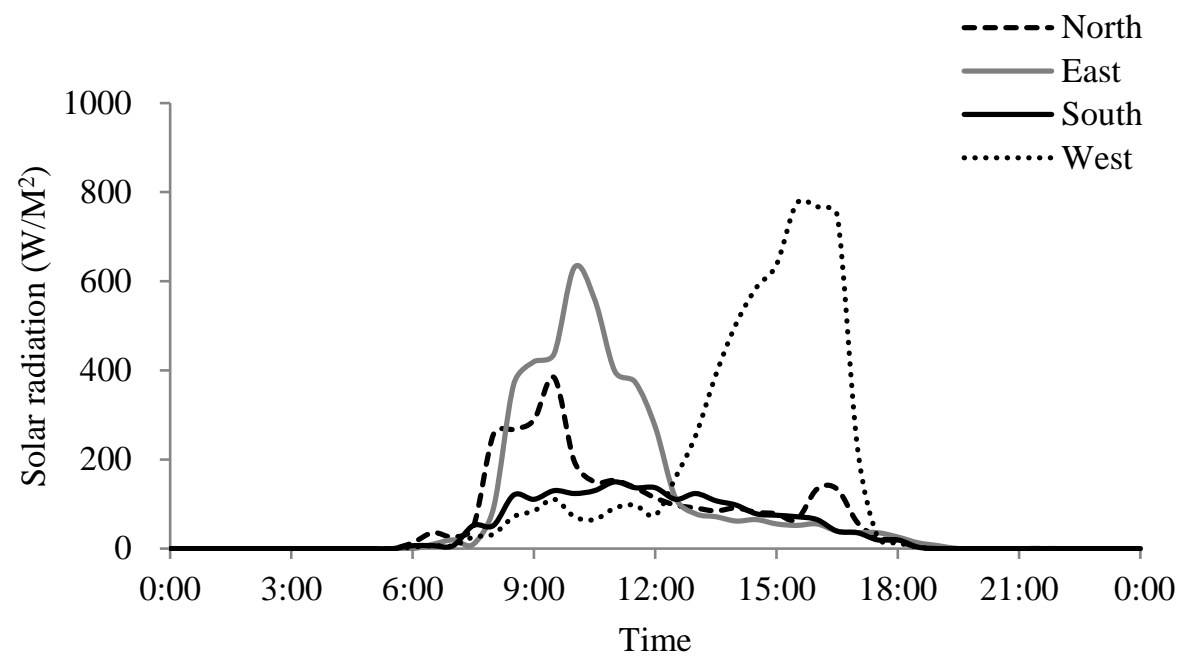

Figure 4. Solar radiation of testing walls in four orientations on 15 July 2014. 

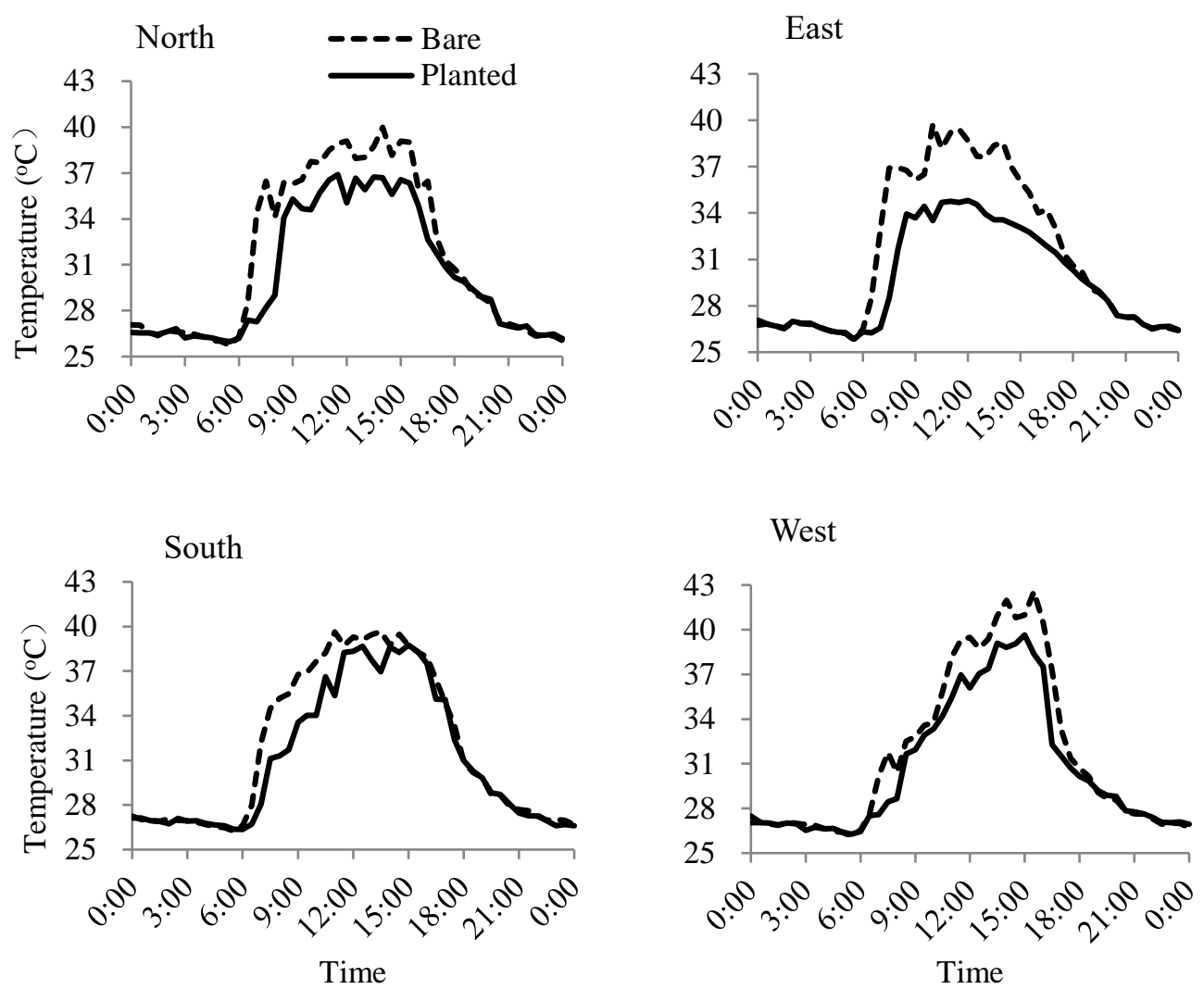

Figure 5. Temperature trends of the ambient air of the bare and planted walls facing north, east, south, and west on 15 July 2014. 


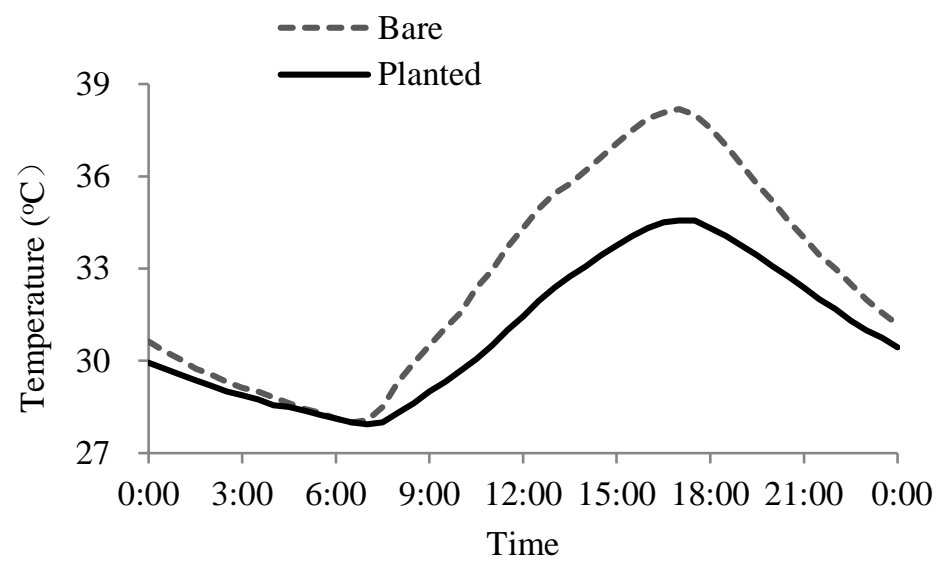

Figure 6. Temperature variations in the indoor air of the testing rooms with and without VGSs on 15 July 2014.
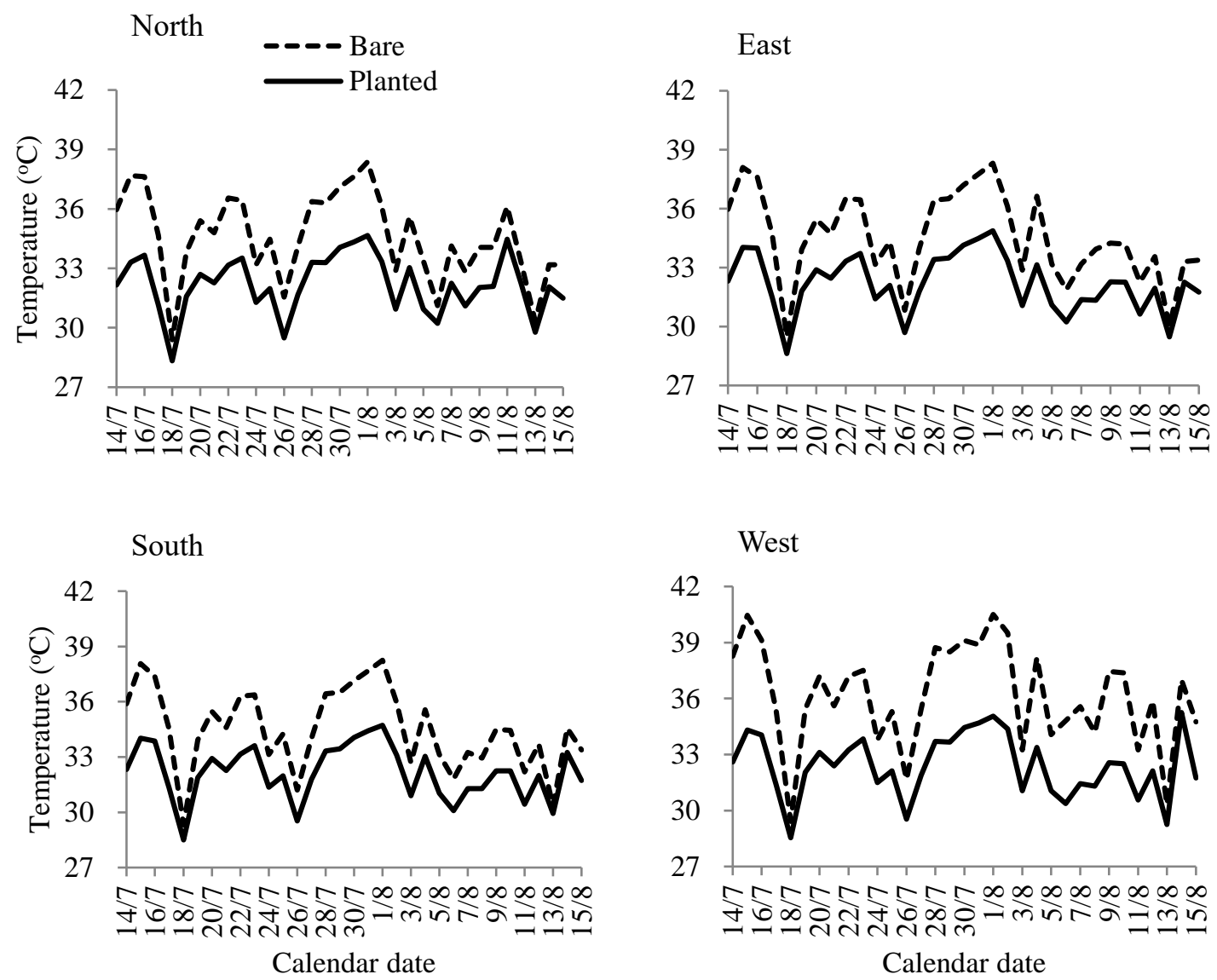

Figure 7. Daily maximum surface temperatures of the bare and planted walls facing north, east, south, and west from 14 July to 15 August 2014. 

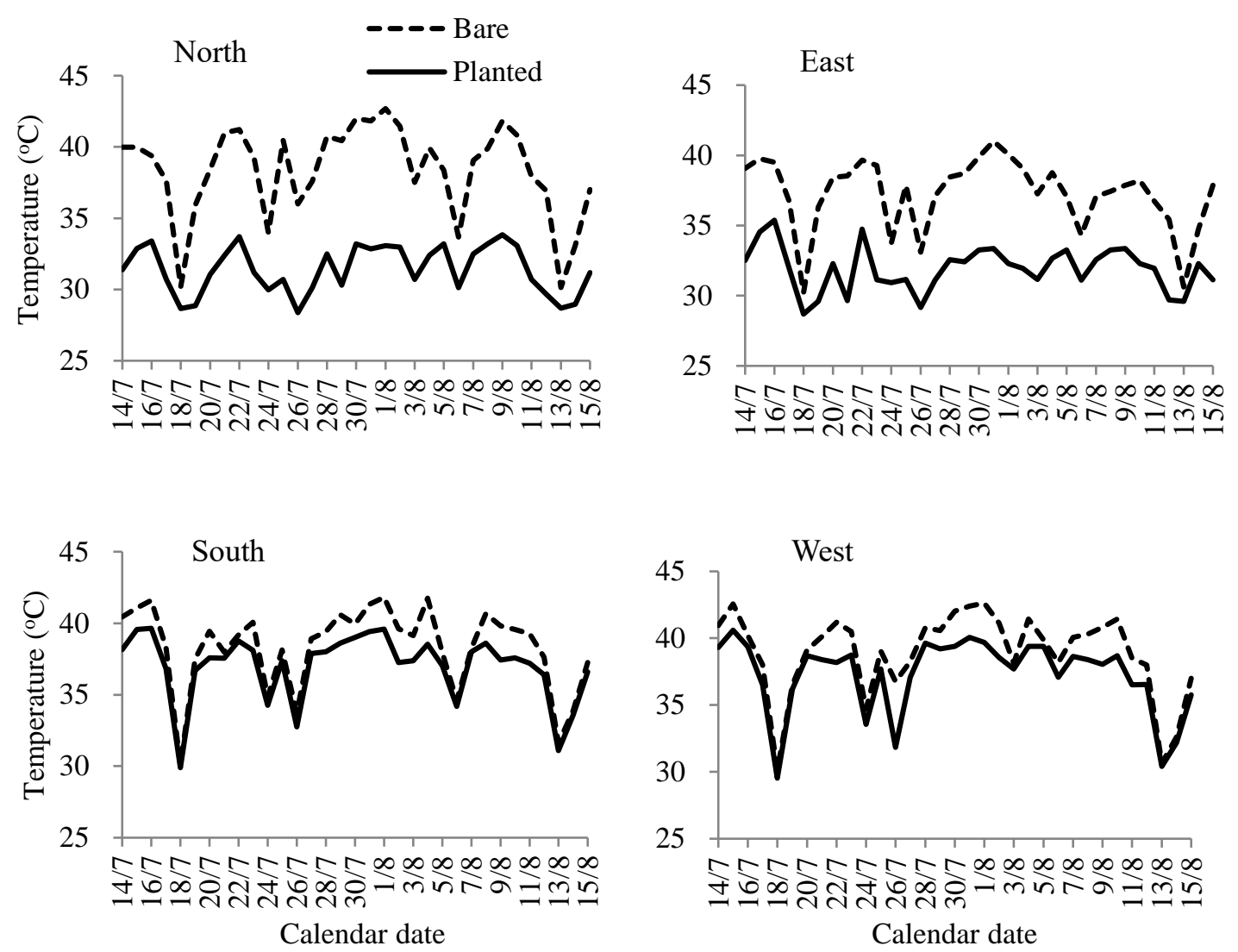

Figure 8. Daily maximum ambient temperature of the bare and planted walls facing north, east, south, and west from 14 July to 15 August 2014.

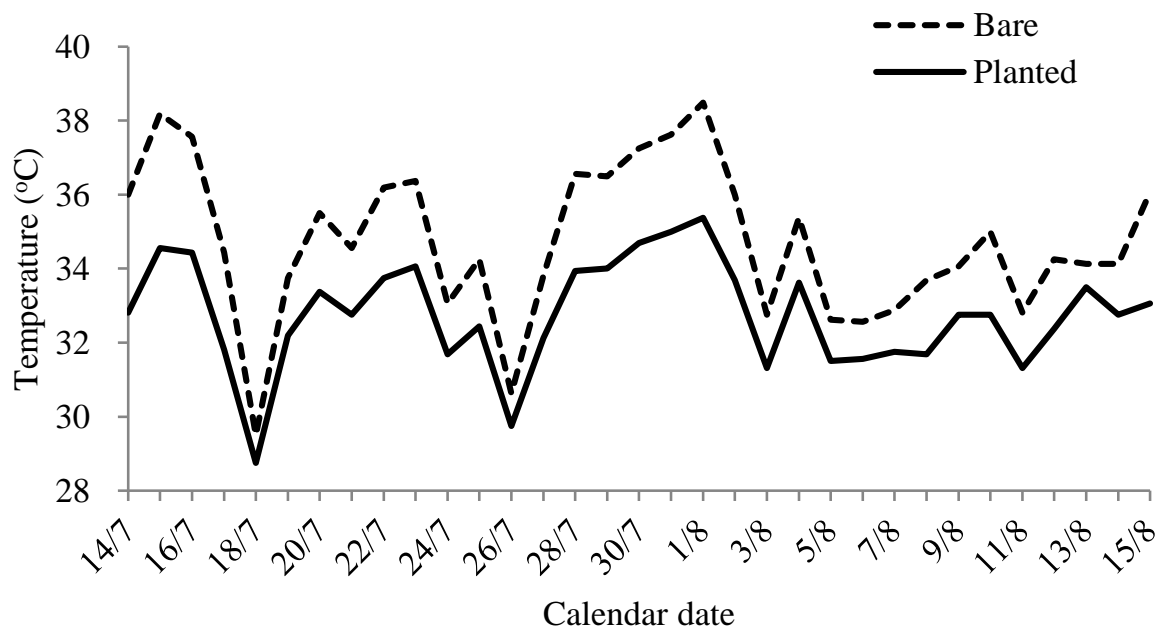

Figure 9. Daily maximum indoor air temperatures of the testing rooms with and without VGSs from 14 July to 15 August 2014. 
(a)

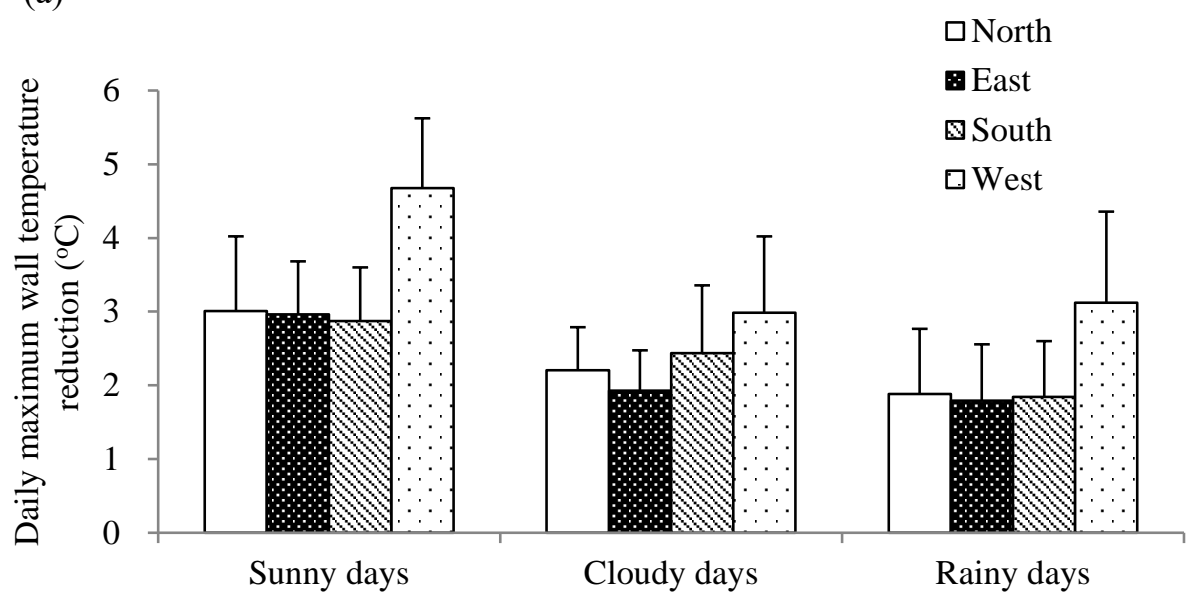

(b)

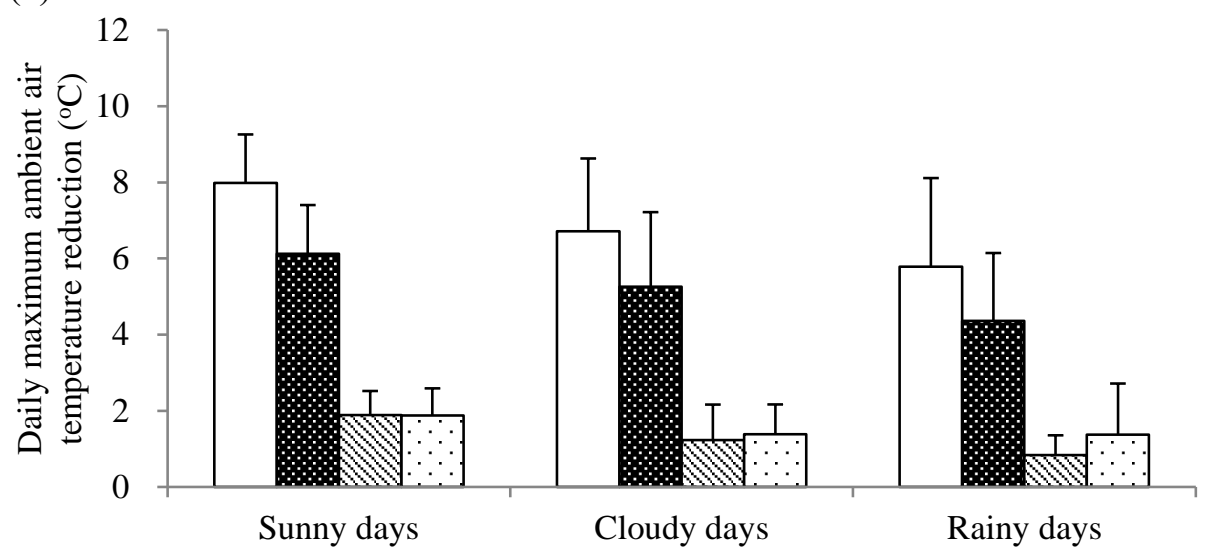

(c)

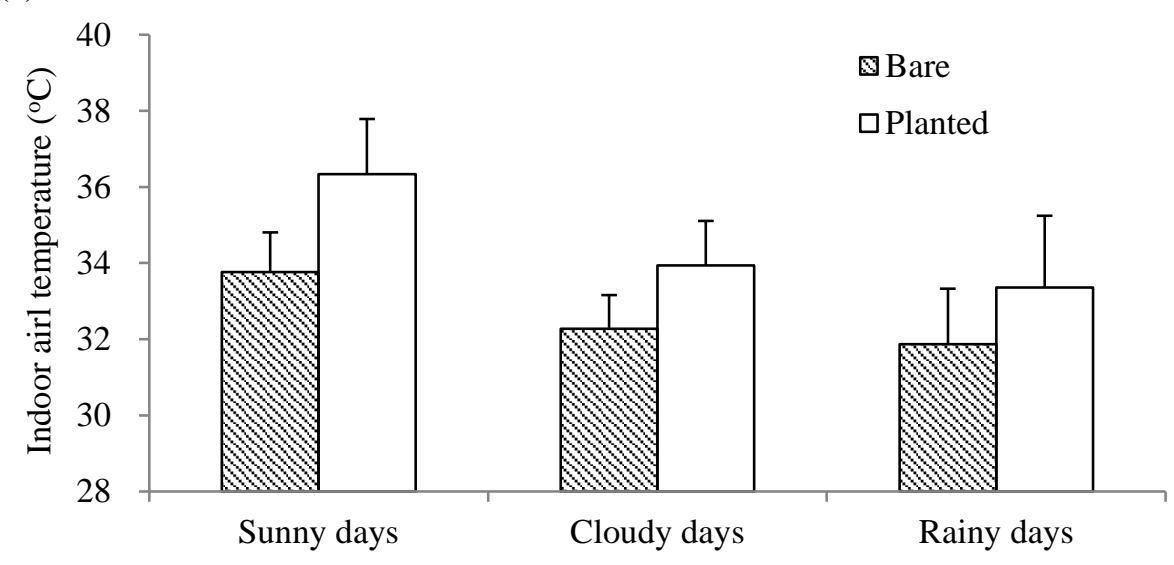

Figure 10. Daily maximum wall temperature reduction (a), daily maximum ambient air temperature reduction (b) and daily maximum indoor air temperatures (c) of VGSs in the four orientations under different weather conditions. Error bars show standard deviation between replicates. 
Table 1. Temperature of the walls with and without VGSs in four orientations on 15 July 2014.

\begin{tabular}{|c|c|c|c|c|c|c|c|}
\hline \multirow{2}{*}{$\begin{array}{l}\text { Orientati } \\
\text { on }\end{array}$} & \multicolumn{2}{|l|}{ Bare wall } & \multicolumn{2}{|c|}{ Planted wall } & \multirow{2}{*}{$\begin{array}{l}\text { Maximum } \\
\text { temperatu } \\
\text { re } \\
\text { reduction } \\
\left({ }^{\circ} \mathrm{C}\right)\end{array}$} & \multirow{2}{*}{$\begin{array}{l}\text { Time with } \\
\text { maximum } \\
\text { temperatu } \\
\text { re } \\
\text { reduction }\end{array}$} & \multirow[b]{2}{*}{$\begin{array}{l}\text { Time with } \\
\text { temperatu } \\
\text { re } \\
\text { reduction } \\
>\quad 3^{\circ} \mathrm{C} \\
\text { (duration / } \\
\text { h) }\end{array}$} \\
\hline & $\begin{array}{l}\text { Wall } \\
\text { temperatu } \\
\text { re range } \\
\left({ }^{\circ} \mathrm{C}\right)\end{array}$ & $\begin{array}{l}\text { Mean } \\
\text { temperatu } \\
\text { re }\left({ }^{\circ} \mathrm{C}\right)\end{array}$ & $\begin{array}{l}\text { Wall } \\
\text { temperatu } \\
\text { re range } \\
\left({ }^{\circ} \mathrm{C}\right)\end{array}$ & $\begin{array}{l}\text { Mean } \\
\text { temperatu } \\
\text { re }\left({ }^{\circ} \mathrm{C}\right)\end{array}$ & & & \\
\hline North & $28.1-38.0$ & 32.8 & $27.7-33.8$ & 30.5 & 4.4 & 1530 & $\begin{array}{l}1000- \\
1830(8.5)\end{array}$ \\
\hline East & $28.0-38.1$ & 33.0 & $28.0-34.0$ & 30.9 & 4.1 & 1130 & $\begin{array}{l}0930- \\
1830(9)\end{array}$ \\
\hline South & $28.0-38.1$ & 32.6 & $27.8-34.0$ & 30.6 & 4.0 & 1530 & $\begin{array}{l}1100- \\
1800(7)\end{array}$ \\
\hline West & $28.1-40.5$ & 33.0 & $27.8-34.3$ & 30.6 & 6.4 & 1530 & $\begin{array}{l}1100- \\
1900(8)\end{array}$ \\
\hline
\end{tabular}

Table 2. Ambient temperatures of the walls with and without VGSs in four orientations on 15 July 2014.

\begin{tabular}{|c|c|c|c|c|c|c|c|}
\hline \multirow{2}{*}{$\begin{array}{l}\text { Orientati } \\
\text { on }\end{array}$} & \multicolumn{2}{|l|}{ Bare wall } & \multicolumn{2}{|c|}{ Planted wall } & \multirow[b]{2}{*}{$\begin{array}{l}\text { Maximum } \\
\text { temperatu } \\
\text { re } \\
\text { reduction } \\
\left({ }^{\circ} \mathrm{C}\right)\end{array}$} & \multirow[b]{2}{*}{$\begin{array}{l}\text { Time with } \\
\text { maximum } \\
\text { temperatu } \\
\text { re } \\
\text { reduction }\end{array}$} & \multirow[b]{2}{*}{$\begin{array}{l}\text { Time with } \\
\text { temperatu } \\
\text { re } \\
\text { reduction } \\
>3^{\circ} \mathrm{C} \\
\text { (duration } \\
/ \mathrm{h} \text { ) }\end{array}$} \\
\hline & $\begin{array}{l}\text { Ambient } \\
\text { temperatu } \\
\text { re range } \\
\left({ }^{\circ} \mathrm{C}\right)\end{array}$ & $\begin{array}{l}\text { Mean } \\
\text { temperatu } \\
\text { re }\left({ }^{\circ} \mathrm{C}\right)\end{array}$ & $\begin{array}{l}\text { Ambient } \\
\text { temperatu } \\
\text { re range } \\
\left({ }^{\circ} \mathrm{C}\right)\end{array}$ & $\begin{array}{l}\text { Mean } \\
\text { temperatu } \\
\text { re }\left({ }^{\circ} \mathrm{C}\right)\end{array}$ & & & \\
\hline North & $25.7-40.0$ & 31.6 & $26.0-36.9$ & 30.3 & 8.2 & 0730 & $\begin{array}{l}0700- \\
0800 \text { (1) }\end{array}$ \\
\hline East & $25.8-39.7$ & 31.4 & $25.8-34.8$ & 29.7 & 8.4 & 0730 & $\begin{array}{l}0700- \\
0800, \\
1000- \\
1500(5)\end{array}$ \\
\hline South & $26.3-39.7$ & 31.9 & $26.4-38.8$ & 31.0 & 3.1 & 1100 & $\begin{array}{l}0700- \\
1000(3)\end{array}$ \\
\hline West & $26.1-42.6$ & 31.6 & $26.3-39.6$ & 30.6 & 4.7 & 1630 & $\begin{array}{l}1530- \\
1630(1)\end{array}$ \\
\hline
\end{tabular}


Table 3. Wall temperature dynamics of testing rooms with and without VGSs in four orientations from 14 July to 15 August 2014 (33 days).

\begin{tabular}{|c|c|c|c|c|c|c|c|c|}
\hline \multirow{2}{*}{$\begin{array}{l}\text { Orientati } \\
\text { on }\end{array}$} & \multicolumn{3}{|c|}{ Bare wall } & \multicolumn{3}{|c|}{ Planted wall } & \multirow[b]{2}{*}{$\begin{array}{l}\text { Minimu } \\
\mathrm{m} \\
\text { temperat } \\
\text { ure } \\
\text { reduction } \\
\left({ }^{\circ} \mathrm{C}\right)\end{array}$} & \multirow[b]{2}{*}{$\begin{array}{l}\text { Maximu } \\
\mathrm{m} \\
\text { temperat } \\
\text { ure } \\
\text { reduction } \\
\left({ }^{\circ} \mathrm{C}\right)\end{array}$} \\
\hline & $\begin{array}{l}\text { Wall } \\
\text { temperatu } \\
\text { re range } \\
\left({ }^{\circ} \mathrm{C}\right)\end{array}$ & $\begin{array}{l}\text { Mean } \\
\text { wall } \\
\text { temperatu } \\
\text { re }\left({ }^{\circ} \mathrm{C}\right)\end{array}$ & $\begin{array}{l}\text { Day } \\
\mathrm{s}> \\
35^{\circ} \\
\mathrm{C}\end{array}$ & $\begin{array}{l}\text { Wall } \\
\text { temperat } \\
\text { ure range } \\
\left({ }^{\circ} \mathrm{C}\right)\end{array}$ & $\begin{array}{l}\text { Mean } \\
\text { wall } \\
\text { temperat } \\
\text { ure }\left({ }^{\circ} \mathrm{C}\right)\end{array}$ & $\begin{array}{l}\text { Day } \\
\mathrm{s}> \\
35^{\circ} \\
\mathrm{C}\end{array}$ & & \\
\hline North & 29.4-38.4 & 34.6 & 14 & $28.3-34.7$ & 32.2 & 0 & 0.5 & 4.4 \\
\hline East & $29.5-38.3$ & 34.5 & 13 & $28.6-34.9$ & 32.2 & 0 & 0.5 & 4.1 \\
\hline South & $29.3-38.3$ & 34.5 & 13 & $28.5-34.7$ & 32.2 & 0 & 0.4 & 4.0 \\
\hline West & $29.4-40.5$ & 36.2 & 23 & $28.5-35.3$ & 32.4 & 2 & 0.9 & 6.1 \\
\hline
\end{tabular}

Table 4. Ambient temperature dynamics of testing rooms with and without VGSs in four orientations from 14 July to 15 August 2014 (33 days).

\begin{tabular}{|c|c|c|c|c|c|c|c|c|c|c|}
\hline \multirow{2}{*}{$\begin{array}{l}\text { Orient } \\
\text { ation }\end{array}$} & \multicolumn{4}{|c|}{ Bare wall } & \multicolumn{4}{|c|}{ Planted wall } & \multirow[b]{2}{*}{$\begin{array}{l}\text { Minim } \\
\text { um } \\
\text { temper } \\
\text { ature } \\
\text { reducti } \\
\text { on } \\
\left({ }^{\circ} \mathrm{C}\right) \\
\end{array}$} & \multirow[b]{2}{*}{$\begin{array}{l}\text { Maxi } \\
\text { mum } \\
\text { temper } \\
\text { ature } \\
\text { reducti } \\
\text { on } \\
\left({ }^{\circ} \mathrm{C}\right)\end{array}$} \\
\hline & $\begin{array}{l}\text { Ambie } \\
\mathrm{nt} \\
\text { temper } \\
\text { ature } \\
\text { range } \\
\left({ }^{\circ} \mathrm{C}\right)\end{array}$ & $\begin{array}{l}\text { Mean } \\
\text { ambie } \\
\mathrm{nt} \\
\text { temper } \\
\text { ature } \\
\left({ }^{\circ} \mathrm{C}\right)\end{array}$ & $\begin{array}{l}\text { Day } \\
\text { excee } \\
\text { ding } \\
35^{\circ} \mathrm{C}\end{array}$ & $\begin{array}{l}\text { Day } \\
\text { excee } \\
\text { ding } \\
40^{\circ} \mathrm{C}\end{array}$ & $\begin{array}{l}\text { Ambie } \\
\text { nt } \\
\text { temper } \\
\text { ature } \\
\text { range } \\
\left({ }^{\circ} \mathrm{C}\right)\end{array}$ & $\begin{array}{l}\text { Mean } \\
\text { ambie } \\
\mathrm{nt} \\
\text { temper } \\
\text { ature } \\
\left({ }^{\circ} \mathrm{C}\right)\end{array}$ & $\begin{array}{l}\text { Days } \\
\text { excee } \\
\text { ding } \\
35^{\circ} \mathrm{C}\end{array}$ & $\begin{array}{l}\text { Days } \\
\text { excee } \\
\text { ding } \\
40^{\circ} \mathrm{C}\end{array}$ & & \\
\hline North & $\begin{array}{l}30.1- \\
42.7\end{array}$ & 38.4 & 28 & 11 & $\begin{array}{l}28.4- \\
33.8\end{array}$ & 31.4 & 0 & 0 & 1.5 & 10.1 \\
\hline East & $\begin{array}{l}30.2- \\
41.0\end{array}$ & 37.3 & 27 & 2 & $\begin{array}{l}28.7- \\
35.4\end{array}$ & 31.9 & 1 & 0 & 1.0 & 8.9 \\
\hline South & $\begin{array}{l}30.1- \\
41.8\end{array}$ & 38.3 & 27 & 9 & $\begin{array}{l}29.9- \\
39.6\end{array}$ & 37.0 & 27 & 0 & 0.2 & 3.2 \\
\hline West & $\begin{array}{l}30.1- \\
42.6\end{array}$ & 38.9 & 29 & 17 & $\begin{array}{l}29.5- \\
40.6\end{array}$ & 37.3 & 28 & 2 & 0.2 & 4.9 \\
\hline
\end{tabular}


Table 5. Effects of orientation and weather on daily maximum wall temperature, daily maximum ambient air temperature, and daily maximum indoor air temperature of the testing rooms with and without VGSs.

\begin{tabular}{|c|c|c|c|c|}
\hline \multirow[t]{3}{*}{ Parameters } & \multicolumn{4}{|c|}{ Level of significance (p) } \\
\hline & Orientation & Weather & Orientation & $\times$ \\
\hline & & \multicolumn{3}{|c|}{ Weather } \\
\hline $\begin{array}{l}\text { Daily maximum wall } \\
\text { temperature }\end{array}$ & $<0.001$ & $<0.001$ & 0.536 & \\
\hline $\begin{array}{l}\text { Daily maximum ambient } \\
\text { air temperature }\end{array}$ & $<0.001$ & $<0.001$ & 0.117 & \\
\hline $\begin{array}{l}\text { Daily maximum indoor air } \\
\text { temperature }\end{array}$ & $<0.001$ & $<0.001$ & 0.327 & \\
\hline
\end{tabular}


Table 6. Pearson correlation coefficients for weather parameters and thermal indicators of the VGSs in four orientations.

\begin{tabular}{|c|c|c|c|c|c|c|c|}
\hline Temperatures & & $\begin{array}{l}\text { Mean air } \\
\text { temperature } \\
\left({ }^{\circ} \mathrm{C}\right)\end{array}$ & $\begin{array}{l}\text { Solar } \\
\text { radiation } \\
\left(\mathrm{W} / \mathrm{m}^{2}\right)\end{array}$ & $\begin{array}{l}\text { Total bright } \\
\text { sunshine (h) }\end{array}$ & $\begin{array}{l}\text { Relative } \\
\text { humidity } \\
(\%)\end{array}$ & $\begin{array}{l}\text { Mean } \\
\text { cloud } \\
\text { amount } \\
(\%)\end{array}$ & $\begin{array}{l}\text { Wind } \\
\text { speed } \\
(\mathrm{m} / \mathrm{s})\end{array}$ \\
\hline \multicolumn{8}{|l|}{$\underline{\text { North }}$} \\
\hline \multirow[t]{3}{*}{$\begin{array}{l}\text { Ambient } \\
\text { temperature }\end{array}$} & Bare wall & $0.742 * *$ & $0.591 * *$ & $0.754 * *$ & $-0.742 * *$ & $-0.636^{* *}$ & $-0.662 * *$ \\
\hline & Planted wall & $0.596^{* *}$ & $0.520 * *$ & $0.600 * *$ & $-0.564 * *$ & $-0.557 * *$ & $-0.519 * *$ \\
\hline & Reduction & $0.672 * *$ & $0.500 * *$ & $0.689 * *$ & $-0.698 * *$ & $-0.539 * *$ & $-0.610 * *$ \\
\hline \multirow{3}{*}{$\begin{array}{l}\text { Wall } \\
\text { temperature }\end{array}$} & Bare wall & $0.758^{* *}$ & $0.688^{* *}$ & $0.691 * *$ & $-0.752 * *$ & $-0.562 * *$ & $-0.473 * *$ \\
\hline & Planted wall & $0.721 * *$ & $0.635^{* *}$ & $0.676^{* *}$ & $-0.678^{* *}$ & $-0.597 * *$ & $-0.478 * *$ \\
\hline & Reduction & $0.660 * *$ & $0.627^{* *}$ & $0.574 * *$ & $-0.708^{* *}$ & $-0.398^{*}$ & $-0.370^{*}$ \\
\hline \multicolumn{8}{|l|}{$\underline{\text { East }}$} \\
\hline \multirow[t]{3}{*}{$\begin{array}{l}\text { Ambient } \\
\text { temperature }\end{array}$} & Bare wall & $0.796^{* *}$ & $0.687 * *$ & $0.822 * *$ & $-0.781 * *$ & $-0.671 * *$ & $-0.645 * *$ \\
\hline & Planted wall & $0.492 * *$ & $0.603 * *$ & $0.539 * *$ & $-0.492 * *$ & $-0.428^{*}$ & $-0.447 * *$ \\
\hline & Reduction & $0.678^{* *}$ & $0.430^{*}$ & $0.673 * *$ & $-0.657^{* *}$ & $-0.560^{* *}$ & $-0.507^{* *}$ \\
\hline \multirow{3}{*}{$\begin{array}{l}\text { Wall } \\
\text { temperature }\end{array}$} & Bare wall & $0.764 * *$ & $0.743^{* *}$ & $0.744^{* *}$ & $-0.772 * *$ & $-0.637 * *$ & $-0.480 * *$ \\
\hline & Planted wall & $0.748^{* *}$ & $0.746^{* *}$ & $0.741 * *$ & $-0.741 * *$ & $-0.663 * *$ & $-0.481 * *$ \\
\hline & Reduction & $0.701 * *$ & $0.650 * *$ & $0.660 * *$ & $-0.731 * *$ & $-0.518^{* *}$ & $-0.421^{*}$ \\
\hline \multicolumn{8}{|l|}{$\underline{\text { South }}$} \\
\hline \multirow[t]{3}{*}{$\begin{array}{l}\text { Ambient } \\
\text { temperature }\end{array}$} & Bare wall & $0.766^{* *}$ & $0.588^{* *}$ & $0.778^{* *}$ & $-0.727 * *$ & $-0.554 * *$ & $-0.598 * *$ \\
\hline & Planted wall & $0.765^{* *}$ & $0.585^{* *}$ & $0.766^{* *}$ & $-0.740 * *$ & $-0.561^{* *}$ & $-0.635^{* *}$ \\
\hline & Reduction & $0.505^{* *}$ & $0.387^{*}$ & $0.547 * *$ & $-0.439 *$ & $-0.343^{*}$ & -0.285 \\
\hline \multirow{3}{*}{$\begin{array}{l}\text { Wall } \\
\text { temperature }\end{array}$} & Bare wall & $0.662 * *$ & $0.735^{* *}$ & $0.650 * *$ & $-0.671 * *$ & $-0.582 * *$ & $-0.447 * *$ \\
\hline & Planted wall & $0.686^{* *}$ & $0.731^{* *}$ & $0.695^{* *}$ & $-0.682 * *$ & $-0.630^{* *}$ & $-0.439 * *$ \\
\hline & Reduction & $0.546^{* *}$ & $0.659 * *$ & $0.499 * *$ & $-0.577 * *$ & $-0.435^{*}$ & $-0.409 *$ \\
\hline \multicolumn{8}{|l|}{$\underline{\text { West }}$} \\
\hline \multirow[t]{3}{*}{$\begin{array}{l}\text { Ambient } \\
\text { temperature }\end{array}$} & Bare wall & $0.694 * *$ & $0.585^{* *}$ & $0.717 * *$ & $-0.655^{* *}$ & $-0.576^{* *}$ & $-0.735 * *$ \\
\hline & Planted wall & $0.655^{* *}$ & $0.543 * *$ & $0.711^{* *}$ & $-0.630 * *$ & $-0.520 * *$ & $-0.752 * *$ \\
\hline & Reduction & $0.514 * *$ & $0.486^{* *}$ & $0.442 * *$ & $-0.449 * *$ & -0.313 & -0.302 \\
\hline \multirow{3}{*}{$\begin{array}{l}\text { Wall } \\
\text { temperature }\end{array}$} & Bare wall & $0.659 * *$ & $0.699 * *$ & $0.677 * *$ & $-0.650^{* *}$ & $-0.555^{* *}$ & $-0.519 * *$ \\
\hline & Planted wall & $0.633^{* *}$ & $0.704 * *$ & $0.651^{* *}$ & $-0.622 * *$ & $-0.603 * *$ & $-0.449 * *$ \\
\hline & Reduction & $0.570^{* *}$ & $0.564 * *$ & $0.585^{* *}$ & $-0.567 * *$ & $-0.390 *$ & -0.314 \\
\hline
\end{tabular}

* Correlation is significant at the 0.05 level (2-tailed).

** Correlation is significant at the 0.01 level (2-tailed). 
Table 7. Pearson correlation coefficients among weather parameters and thermal indicators of the VGSs in the testing rooms.

\begin{tabular}{lllllll}
\hline $\begin{array}{l}\text { Indoor } \\
\text { temperatures }\end{array}$ & $\begin{array}{l}\text { Mean air } \\
\text { temperature } \\
\left({ }^{\circ} \mathrm{C}\right)\end{array}$ & $\begin{array}{l}\text { Solar } \\
\text { radiation } \\
\left(\mathrm{W} / \mathrm{m}^{2}\right)\end{array}$ & $\begin{array}{l}\text { Total } \\
\text { bright } \\
\text { sunshine } \\
(\mathrm{h})\end{array}$ & $\begin{array}{l}\text { Relative } \\
\text { humidity } \\
(\%)\end{array}$ & $\begin{array}{l}\text { Mean } \\
\text { cloud } \\
\text { amount } \\
(\%)\end{array}$ & $\begin{array}{l}\text { Wind } \\
\text { speed } \\
(\mathrm{m} / \mathrm{s})\end{array}$ \\
\hline Bare wall & $0.624^{* *}$ & $0.733^{* *}$ & $0.713^{* *}$ & $-0.664^{* *}$ & $-0.631^{* *}$ & -0.317 \\
Planted wall & $0.526^{* *}$ & $0.647^{* *}$ & $0.631^{* *}$ & $-0.552^{* *}$ & $-0.610^{* *}$ & -0.271 \\
Reduction & $0.686^{* *}$ & $0.752^{* *}$ & $0.728^{* *}$ & $-0.746^{* *}$ & $-0.547^{* *}$ & $-0.342^{*}$ \\
\hline
\end{tabular}

* Correlation is significant at the 0.05 level (2-tailed).

** Correlation is significant at the 0.01 level (2-tailed).

Table 8. Heat conduction of example rooms with and without VGSs.

\begin{tabular}{|c|c|c|c|c|c|c|c|}
\hline \multirow[t]{2}{*}{ Orientation } & \multicolumn{2}{|c|}{ Without VGSs } & \multicolumn{2}{|c|}{ With VGSs } & \multirow{2}{*}{$\begin{array}{l}\text { Heat } \\
\text { conduction } \\
\text { reduction } \\
\text { (W) }\end{array}$} & \multirow{2}{*}{$\begin{array}{l}\text { Heat } \\
\text { conduction } \\
\text { reduction } \\
(\%)\end{array}$} & \multirow{2}{*}{$\begin{array}{l}\text { Heat } \\
\text { conduction } \\
\text { reduction } \\
\text { per unit area } \\
\left(\mathrm{W} / \mathrm{m}^{2}\right)\end{array}$} \\
\hline & $\begin{array}{l}\text { Ambient } \\
\text { temperatur } \\
\text { e }\left({ }^{\circ} \mathrm{C}\right)\end{array}$ & $\begin{array}{l}\text { Heat } \\
\text { conducti } \\
\text { on (W) }\end{array}$ & $\begin{array}{l}\text { Canopy } \\
\text { temperatur } \\
\text { e }\left({ }^{\circ} \mathrm{C}\right)\end{array}$ & $\begin{array}{l}\text { Heat } \\
\text { conduction } \\
\text { (W) }\end{array}$ & & & \\
\hline North & 40.6 & 98.5 & 34.1 & 57.5 & 41.0 & 41.6 & 2.28 \\
\hline East & 40.1 & 95.3 & 34.6 & 60.2 & 35.1 & 36.8 & 1.95 \\
\hline South & 40.1 & 94.9 & 37.3 & 77.2 & 17.7 & 18.7 & 0.98 \\
\hline West & 40.9 & 100.0 & 38.9 & 87.6 & 12.4 & 12.4 & 0.69 \\
\hline Average & 40.4 & 97.2 & 36.2 & 70.6 & 26.5 & 27.3 & 1.47 \\
\hline
\end{tabular}

